\title{
LORENZ, Sönke, SCHOLKMANN, Barbara, Die Alemannen und das Christentum. Zeugnisse eines kulturellen Umbruchs
}

\section{Philippe Depreux}

\section{(2) OpenEdition \\ Journals}

Édition électronique

URL : http://journals.openedition.org/ifha/846

DOI : 10.4000/ifha.846

ISSN : 2198-8943

Éditeur

IFRA - Institut franco-allemand (sciences historiques et sociales)

Référence électronique

Philippe Depreux, «LORENZ, Sönke, SCHOLKMANN, Barbara, Die Alemannen und das Christentum. Zeugnisse eines kulturellen Umbruchs », Revue de l'IFHA [En ligne], Date de recension, mis en ligne le 01 janvier 2005, consulté le 22 septembre 2020. URL : http://journals.openedition.org/ifha/846 ; DOI : https://doi.org/10.4000/ifha.846

Ce document a été généré automatiquement le 22 septembre 2020.

(CIFHA 


\title{
LORENZ, Sönke, SCHOLKMANN, Barbara, Die Alemannen und das Christentum. Zeugnisse eines kulturellen Umbruchs
}

\author{
Philippe Depreux
}

1 Ce volume constitue les actes d'une rencontre scientifique organisée parallèlement à l'exposition de 1997 consacrée aux Alamans. Il s'agit d'un volume assez hétéroclite, où la question de la christianisation des Alamans est appréhendée à la fois d'après les sources écrites (notamment en ce qui concerne l'analyse des formes que revêt, dans les textes juridiques, la notion de " religieux ») et, tout particulièrement, archéologiques, qu'il s'agisse d'interpréter la présence de croix en or dans les sépultures groupées (où l'on ne peut pas vraiment distinguer de périmètres « chrétiens ») illustrant les liens, par delà les Alpes, avec les Lombards, ou qu'il s'agisse, principalement, de l'interprétation des plans d'églises, de pierre ou de bois, qui posent le problème de la permanence du christianisme tardo-antique. Or, si l'on raisonne à partir des structures - foncières, mais surtout ecclésiales -, force est de souligner la césure que représente le milieu du VIIIe s., qu'il s'avère toutefois bien difficile d'appréhender en s'affranchissant de certains modèles construits a posteriori (tel celui des " églises privées ») et des sirènes de la méthode régressive. Il s'agit là d'une contribution à une approche croisée des sources archéologiques et historiques à propos d'une région particulièrement riche du point de vue documentaire.

Philippe DEPREUX (MHFA) 